\title{
Development of Gamyflip-Pro Module and Determination of Its Content Validity
}

\author{
Azia Sulong, Abu Bakar Ibrahim, Ashardi Abas
}

To Link this Article: http://dx.doi.org/10.6007/IJARBSS/v9-i7/6790

DOI:10.6007/IJARBSS/v9-i7/6790

Received: 10 May 2019, Revised: 17 June 2019, Accepted: 30 June 2019

Published Online: 01 July 2019

In-Text Citation: (Sulong et al., 2019)

To Cite this Article: Sulong, A., Ibrahim, A. B., \& Abas, A. (2019). Development of Gamyflip-Pro Module and Determination of Its Content Validity. International Journal of Academic Research in Business and Social Sciences, 9(7), 1427-1436.

\section{Copyright: @ 2019 The Author(s)}

Published by Human Resource Management Academic Research Society (www.hrmars.com)

This article is published under the Creative Commons Attribution (CC BY 4.0) license. Anyone may reproduce, distribute, translate and create derivative works of this article (for both commercial and non-commercial purposes), subject to full attribution to the original publication and authors. The full terms of this license may be seen at: http://creativecommons.org/licences/by/4.0/legalcode

\section{Vol. 9, No. 7, 2019, Pg. 1427 - 1436}




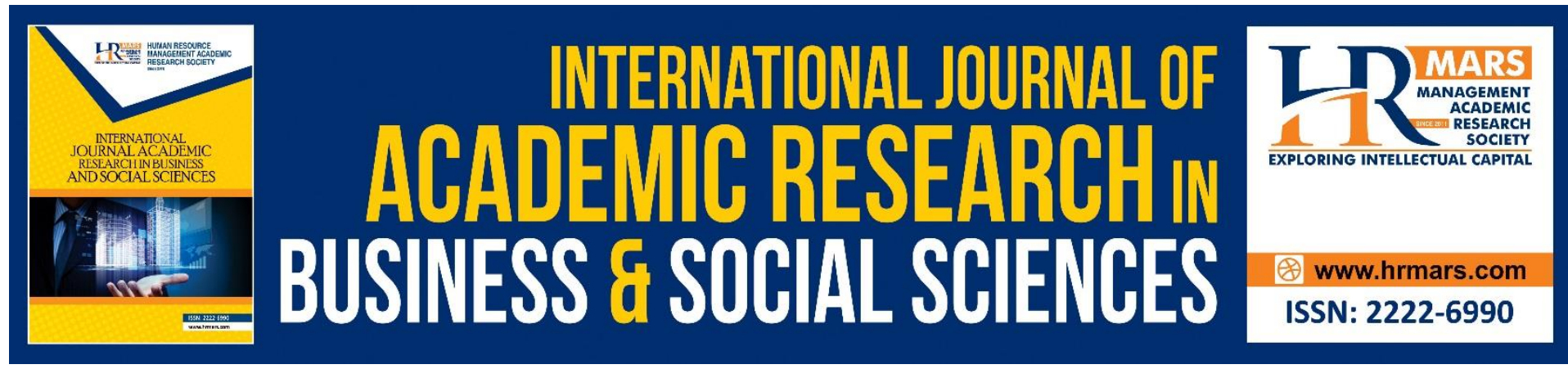

\title{
Development of Gamyflip-Pro Module and Determination of Its Content Validity
}

\author{
Azia Sulong, Abu Bakar Ibrahim, Ashardi Abas \\ Department of Information Technology, Faculty of Art, Computing and Creative \\ Industry, Sultan Idris Education University, Tanjong Malim, 35900, Malaysia
}

\begin{abstract}
In recent years, the integration of Flipped Classroom and gamification in teaching and learning process became popular in order to provide flexibility in teaching and learning process. The purpose of this study was to develop and validate the content of GamyFlip-Pro module in teaching and learning a topic Programming for pre-university students. This module was developed based on Sidek and Jamaludin's Model, Flipped Classroom Approach, and The Five Steps of Applying Gamification in Education by Huang and Soman. The development process involves two main process namely; development of module draft, experts' reviews and implementation of content validity for the modules. Since the development of module draft complete, five subject matter experts will review the module draft. Then, module modification was done based on suggestion and recommendations by subject matter experts followed by the process of calculation content validity of the module. The percentage of experts' agreement obtained for this module ranged from $73 \%$ to $90 \%$. This finding shows that GamyFlip-Pro module has a good content validity. This finding reinforces the use of flipped classroom and gamification approach in the design of teaching and learning modules and establish the pedagogy of flipped learning and gamification in teaching programming.
\end{abstract}

Keywords: Flipped Classroom, Gamification, Module Development, Programming

\section{Introduction}

Flipped classroom and gamification are two increasingly popular approaches in Education field. Flipped learning was practiced by combined face-to-face and nonface to face teaching and learning approach (Zainuddin \& Halili, 2016). According to Holland \& Holland, (2014) and Zainuddin (2018) flipped classroom is a modern pedagogical approach which is gaining popular among an educator. The study on impact of flipped classroom to the student reported that the flipped classroom gave the positive impact toward students' achievement, engagement, motivation and interaction (Trpkovska, Bexheti, \& Cico, 2017; Tugun, Uzunboylu, \& Ozdamli, 2017). Moreover, it is also proven that this approach promotes active participation of students and flexibility within educational processes (Flores \& Silva, 2016). Through the flipped classroom practice, the classroom transform into an active, dynamic and 
authentic where educator guides and facilitate the students to apply the concepts and engage creatively in the subject matter (Holland \& Holland, 2014; Hwang \& Lai, 2017).

Gamification defined as the use of game elements in the non-context games setting (Deterding, Dixon, Khaled, \& Nacke, 2011). Games elements such as Point, badges, reward and leaderboard are used to give the new phenomenon in learning activity. According to Kapp (2014) and, Lee and Hammer (2011), gamification increase the student engagement in academic activities and encourage them to learn. Gamification will drive person to take voluntary actions in a predictable way. Although widely implemented in other countries, gamification is relatively a new concept among teachers in Malaysia (Ahmad, Din, Jamaluddin, Fadzillah \& Jabar, 2017; Ong, Yeng, Hong \& Young, 2013; Singh \& Harun, 2016).

Gamified Flipped classroom refers to the incorporating gamification elements with flipped classroom approach. Some study reported that the flipped classroom has no significant effect on student's learning compared to the conventional learning (Boeve et al., 2017; Cakıroglu \& Ozturk, 2017; Chen, Wang, \& Chen, 2014; Clark, 2015; El-Banna, Keengwe, 2014; Long, Cummins \& Waugh, 2017;; Tse et al., 2017; Whitlow \& McNelis, 2017). Chen (2016) reported that the students skipped pre-class activity because they did not get used with pre-class practice. According to Chao, Chen and Chuang (2015), it was hard to make sure that students had truly watched the material for out-class activities. As for this concern, some scholar suggested to incorporate the gamification in flipped classroom approach.

\section{Research Problem}

Education in Malaysia is still not quite vulnerable to this approach and should be studied more (Rahman, Aris, Mohamed, Zaid, \& Abdullah, 2014). According to Lo and Hew (2017), the main problem of this alternative learning is the students not accustomed with this approach and the effect is the student chooses not to do. Grypp and Luebeck, (2015) reported that teachers might not comprehend the value of flipped classroom and unusual to this new instructional approach.

Therefore, this study focuses on the development of structured materials (modules) to be a guide for teachers and students to experience a structured flipped classroom approach and gamification in learning process. According to Nordin (2013) the guidelines on how to implement the new pedagogy should be prepare for the teacher and students. This approach is very different compared to existing conventional way, so the information provided prior to implementation can help teachers and students to accept something new (Rahman, Aris, Mohamed, Zaid, \& Abdullah, 2014). Components provided in a transactional manner have a consistent and effective effect on the success of the student (fund, 2007).

\section{Research Objective}

This study was undertaken to:

i. Identify the need to develop the GamyFlip-Pro module for a programming topic.

ii. Develop the GamyFlip-Pro module for pre-university students for the topic Problem Solving in Programming. 
iii. Determine the validity of the GamyFlip-Pro module.

\section{Methods}

The development of GamyFlip-Pro module consists of three phases; conducting a need analysis study, development of GamyFlip-Pro draft module and determine the validity of the module.

Need analysis study conducted by researcher using the researchers' developed questionnaire. Its conducted to the 10 Computer Sciences' lecturers who were selected using purposive sampling and 30 students who learns Computer Science subjects. According to Creswell (2014), even the number of samples is small, it allows the researcher to investigate what has been studied more because the samples have in-depth information and familiar with the study.

After completing need analysis process, the next phase is development of GamyFlip-Pro draft module based on findings of theory, needs analysis, current and relevant literature, and curriculum review. This module developed based on Sidek and Jamaludin's model which is suggests nine steps: 1) goal building, 2) identifying theories, rationales, philosophies, concepts, targets and timeframes, 3) need analysis, 4) setting objectives, 5) content selection, 6) strategy selection,7) logistics selection, 8) media selection and 9) combining the module draft. The Figure 1 show the steps of module development by Sidek and Jamaludin.

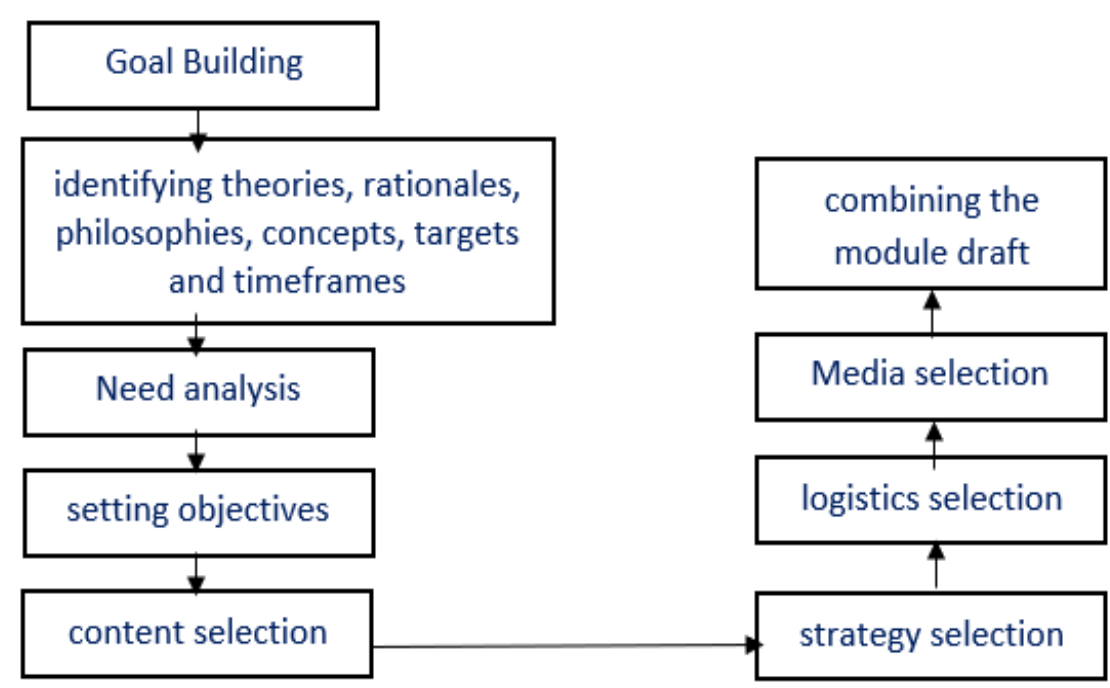

Figure 1. The nine steps of Modul development phase proposed by Sidek and Jamaludin (2005).

Flipped classroom approach by Sams and Bergmann (2012) were chosen as a theoretical for implementing the teaching and learning activities environment. The activities divided into two timeframes; out-class activities and in-class activities. The activities designed for out-class activities more to give the basic concept of learning 
content using relevant learning material while in-class activities designed to clear and enhance student understanding based on what they had learn before class (out-class activities).

In order to implement gamification approach in teaching and learning Problem Solving in Programming in the classroom, the Five Steps of Applying Gamification in Education proposed by Huang and Soman (2013) is embedded as a basic theoretical guideline in the development of GamyFlip-Pro module shown in Figure 2.

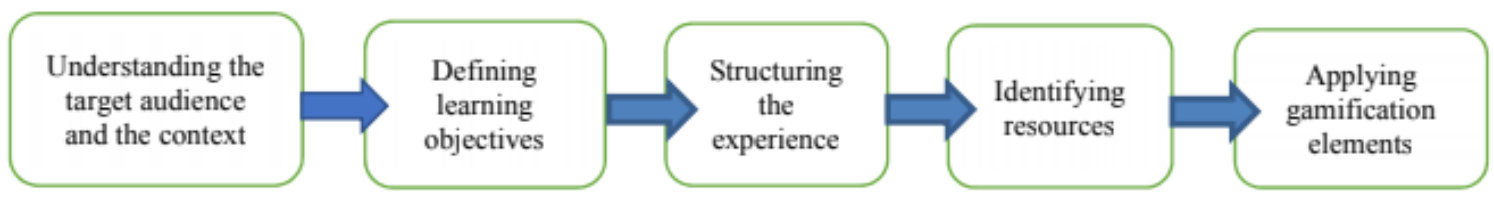

Figure 2. The Five Steps of Applying Gamification in Education proposed by Huang and Soman (2013).

Refer to the figure above, the step start with understanding the target audience consist of audiences' age, learning abilities, skills, environment, students group size and the time frame of activities are crucial to help in designing a proper gamified lesson plan following by second step; defining the learning objectives which is comprises of general instructional goal, specific learning goal and the behavioral goal. In this step, the learning objectives stated in this module are derived from the curriculum specification by the Matriculation Division, Ministry of Education for Computer Science subject. Subsequently, in the next step is structuring the gamified experience. It was implemented in classroom setting using level and milestone as a benchmark for the students to achieve certain learning objectives. The last step is the module designer determined the appropriate gamification elements to be applied in the gamified lesson. Gamification elements such as points, level, badges, storyline, leaderboards are the elements to gamified students in learning activities.

Subsequently, in the third phase, is determination for validity of module draft were done. The module draft content has been validated by five expert panels comprises of the academicians and practitioners. The experts were chosen based on their experiences and expertise in module development, Programming contents, flipped classroom approach and gamification. The recommendation and critiques by an expert were identified and amendment was done. According to Sidek and Jamaludin (2005) and Tuckman and Waheed (1981), the content validity is considered as high when the value is exceeding the threshold of $70 \%$ while Yusri, Yusof and Shah (2010) stated that the total value that exceeds $61 \%$ is considered that the module has a good content.

\section{Findings}

\section{Need Analysis Phase}

Collected data then analyzed and founded that there was a need to apply flipped classroom and gamification approach in teaching and learning Programming topic as most of the respondents reported that teaching and learning Programming is 
difficult and time constraint for both teachers and students. Based on the need analysis, the researcher also found out that the students feel demotivated especially when learning the topic problem solving due to the weakness in problem solving skill and it becomes more difficult. The finding also shows that the requirement for development of module and implementation of gamification is high.

\section{Design and Development Phase}

This module covers the topic of Problem Solving in Programming syllabus for pre-university students. Basically, the contents of the module are divided into two sections. The first section is for modules' introduction and the guideline of module. The second section is about teaching and learning activities that is designed based on flipped classroom and gamification approach.

The first section in this module provides a detail information about the flipped classroom and gamification approach and the module's manual to the user. In this section, its divided into seven parts consists of the introduction, module's philosophy, an overview of flipped classroom and gamification, module's rationale, module's objectives, and a manual on using this module.

The second section designed to facilitate the teacher to use the flipped classroom and gamification approach in teaching and serve as a platform for the students to experience a flipped classroom and gamification in a lesson. The first part of this section is storyline. The storyline is used to engage student into the gamified lesson. In the storyline, every student plays a role as a person that have a dream to become the top millionaire. Everyone has an opportunity to be the top millionaire but they need to learn through the course and join the challenge in order to collect the money. After the storyline, the next part consists learning activities presented in the form of daily lesson plans for the whole topic of the problem solving in programming through the approach of flipped classroom and gamification.

Learning activities designed for two different environments suggested by flipped classroom approach; out class and in class. Out class learning activity mostly use a web platform and focus on the user learn the course followed by money reward challenge activity in order to check the user's understanding. while, in class activity students deal with complex issues related to the content topic. In classroom, activities designed to make the students engaged in student-to-student interactions, collaborations, and critical thinking with the instructor serve as a facilitator to support the student through the challenge activity.

These challenges activity divided into three, namely: 1) Money Reward Challenge 2) Property Reward challenge 3) Exclusive Reward Challenge. Every type of challenge provides a platform for student to check their content understanding about subject the content. For the money reward challenge, it consists of different level of question. The value of money indicates the level of question difficulties. The student allowed to buy a property using collected money from the activity challenge. For Property Reward Challenge, student must pass the challenge before they awarded 
with property. The property reward challenge done at every end of the sub unit. The different value of property indicates the level of learning topic. The last challenge is Exclusive Reward Challenge where the student will be tested about overall topic that they had learn. In this challenge, high value of money is awarded to the student. Accumulate property value calculated to determine who will be the top millionaire. Module ended with Design My Property's Look part where students using all the collected property to design their property look at the provided picture. To give a comprehensive overview of the module, Table I is referred.

Table 1: Section of GamyFlip-Pro Module

\begin{tabular}{ll}
\hline \multicolumn{1}{c}{ First Part } & \multicolumn{1}{c}{ Second Part } \\
\hline - Introduction & $\bullet$ storyline \\
- Philosophy & - Train Yourself Course \\
- Overview of flipped classroom & - Money Reward Challenge \\
and gamification & - Property Reward Challenge \\
- Overview of Gamyflip-Pro & - Exclusive Reward Challenge \\
- Module & $\bullet$ Design My Property's Look \\
- Objective of Module & \\
\hline Module manual & \\
\hline
\end{tabular}

\section{Determination of Content Validity Phase}

The content of GamyFlip-Pro module has been validated by five experts comprised of academicians and practitioners. This module is validated in three constructs including content knowledge, module activities and theoretical relation. Expert recommendations are collected to find similarities in ideas for identifying improvements that need to be made. Modification was done according to the suggestions of the expert. The results after computing the content validity of this module presented in Table 2.

Table 2: The value for calculation of content validity of module

\begin{tabular}{cc}
\hline Expert/Practitioner & Percentage (\%) \\
\hline 1 & 82.0 \\
2 & 73.0 \\
3 & 81.0 \\
4 & 90.0 \\
5 & 77.0 \\
\hline
\end{tabular}

The result for the calculation of content validity level by five experts showed a percentage value of more than $61 \%$. Thus, this finding shows that GamyFlip-Pro module developed has a good content validity. 


\section{Conclusion}

In this study, GamyFlip-Pro module is feasible to be use in teaching and learning a topic Problem Solving in Programming. Based on a combination of theoretical and empirical data, this study is hoped to provide a guideline on how to experience learning activities through the integration of flipped classroom approach and gamification at each stage of learning an impact on existing teacher practices and pedagogy. Teacher and students have the opportunities to integrate the flipped classroom approach and experienced with gamified learning. Moreover, this module has been validated to possess high content validity by the judgement of the experts.

The results of this study can be used as a guidance for the persons involved in the planning, development and implementation of the curriculum to enhance the current curriculum, especially computer science subject. The method of teaching and learning in this module can be used as an example for all teacher to be more effective and create meaningful teaching for the students in the aspects of teaching aids, strategies and teaching approaches.

\section{Corresponding Author}

Azia Sulong

Department of Information Technology, Faculty of Art, Computing and Creative Industry

Sultan Idris Education University

35900 Tanjong Malim

Perak, Malaysia

Email: aziasu@gmail.com

\section{References}

Boeve, A. J., Meijer, R. R., Bosker, R. J., Vugteveen, J., Hoekstra, R., \& Albers, C. J. (2017). Implementing the flipped classroom: an exploration of study behaviour and student performance. Higher Education, 74(6), 1015-1032. https://doi.org/10.1007/s10734-016-0104-y

Cakıroglu, U., \& Ozturk, M. (2017). Flipped Classroom with Problem Based Activities : Exploring Self-regulated Learning in a Programming Language Course, 20, 337349.

Chao, C. Y., Chen, Y. T., \& Chuang, K. Y. (2015). Exploring students learning attitude and achievement in flipped learning supported computer aided design curriculum: A study in high school engineering education. Computer Applications in Engineering Education, 23(4), 514-526.

Chen, Y., Wang, Y., \& Chen, N. S. (2014). Is FLIP enough? Or should we use the FLIPPED model instead? Computers \& Education, 79, 16-27.

Clark, K. R. (2015). The effects of the flipped model of instruction on student engagement and performance in the secondary mathematics classroom. Journal of Educators Online, 12(1), 91-115.

Creswell, J. W. (2014). Educational Research: Planning, Conducting and Evaluating Qualitative and Quantitative Research ( $5^{\text {th }}$ ed.) New York, NY. Pearson.

Deterding, S., Dixon, D., Khaled, R., \& Nacke, L. (2011). From game design elements to gamefulness: Defining gamification. Proceedings of the 15th International 
Academic MindTrek Conference on Envisioning Future Media Environments MindTrek'11, 9-11. https://doi.org/10.1145/2181037.2181040

Flores, Ò., \& Silva, P. (2016). The flipped classroom model at the university : analysis based on professors ' and students ' assessment in the educational field. International Journal of Educational Technology in Higher Education, 1-12. https://doi.org/10.1186/s41239-016-0022-1

Holland, J., \& Holland, J. (2014). Implications of Shifting Technology in Education. TechTrends, 58(3), 16-25. https://doi.org/10.1007/s11528-014-0748-3

Huang, W., \& Soman, D. A. (2013). Practitioner's Guide To Gamification Of Education. Research Report Sereis: Behavioural Economics in Action, Rotman School of Management, University of Toronto, 1-29. https://doi.org/10.1111/j.14678535.2011.01259

Hwang, G. J., \& Lai, C. L. (2017). Facilitating and Bridging Out-Of-Class and In-Class Learning: An Interactive E-Book-Based Flipped Learning Approach for Math Courses, 20, 184-197.

Lee, J. J., \& Hammer, J. (2011). Gamification in Education: What, How, Why Bother? Encyclopedia of Library and Information Sciences, Third Edition, 15(2), 27972803. https://doi.org/10.1081/E-ELIS3-120043942

Kapp, K. (2014). Gamification: Separating Fact From Fiction. Chief Learning Officer, 13(3)(March), 42-46. https://doi.org/10.2304/elea.2005.2.1.5

Keengwe, J. (Ed.). (2014). Promoting active learning through the flipped classroom model. IGI Global.

Lo, C. K., \& Hew, K. F. (2017). A critical review of flipped classroom challenges in K-12 education: possible solutions and recommendations for future research. Research and Practice in Technology Enhanced Learning, 12(1), 4. https://doi.org/10.1186/s41039-016-0044-2

Long, T., Cummins, J., \& Waugh, M. (2017). Use of the flipped classroom instructional model in higher education: instructors' perspectives. Journal of Computing in Higher Education, 29(2), 179-200.

Mukherjee, T. C., \& Pillai, K. V. (2013). Exploring the relationship between Learner's attributes and Flipped classroom success in the Malaysian context.

Ahmad, N. M. A., Din, M. N., Jamaluddin, J., Fadzillah, M. N. S., \& Jabar, A. F. (2017). Gamification Of Introductory Accounting Course: When Is The Best Time To Implement It. 2nd Business Management and Computing Research Colloquium, (July), 75-77.

Nordin, A. B. (2013). Kurikulum ke Arah Penghasilan Kemahiran Berfikiran Kritis, Kreatif dan Inovatif. JuKu: Jurnal Kurikulum \& Pengajaran Asia Pasifik, 1(1), 1018. https://doi.org/10.1016/j.sbspro.2012.06.903

Ong, D., Yeng, C. Y., Hong, C. W., \& Young, K. T. (2013). Motivation of learning : An assessment of the practicality and effectiveness of gamification within a tertiary education. In World Academy of Researchers, Educators, and Scholars in Business, Social Sciences, Humanities and Education (In association with the Academy of World Finance, Banking, Management and IT) (Vol. 1, pp. 131-146).

Sams, A., \& Bergmann, J. (2012). Jonathan Bergmann (first edit). United States of America.

Sams, A., \& Bergmann, J. (2013). Flip your students learning. Educational Leadership, 
70, 16-20.

Sidek, M. N. \& Jamaludin, A. (2005). Pembinaan modul: Bagaimana membina modul latihan dan modul akademik. Serdang: Penerbit UPM

Singh, A. K. J. S., \& Harun, R. N. S. R. (2016). Students' experiences and chalenges of learning English Grammar Through Flipped Classroom and Gamification. In Proceedings of the 1st English Education International Conference (EEIC) in conjunction with the 2nd Reciprocal Graduate Research Symposium (RGRS) of the Consortium of Asia-Pacific Education Universities (CAPEU) between Sultan Idris Education University a (pp. 358-361).

Rahman, A. A., Aris, B., Mohamed, H., Zaid, M. N., \& Abdullah, Z. (2014). Flipped classroom dalam konteks Malaysia. In Konvensyen Antarabangsa Jiwa Pendidik.

Trpkovska, M. A., Bexheti, L. A., \& Cico, B. (2017). Enhancing flipped classroom model implementation. 2017 6th Mediterranean Conference on Embedded Computing (MECO), (June), 1-4. https://doi.org/10.1109/MECO.2017.7977138

Tse, W. S., Choi, L. Y., \& Tang, W. S. (2017). Effects of video-based flipped class instruction on subject reading motivation. British Journal of Educational Technology (In press).

Tuckman, B. W., Waheed, M. A. (1981). Evaluating an Individualized Science Programme for Community College Students. Journal of Research in Science Teaching.18, 489-495

Tugun, V., Uzunboylu, H., \& Ozdamli, F. (2017). Coding Education in a Flipped Classroom. TEM, 6(3), 599-606. https://doi.org/10.18421/TEM63-23

Yusri, G., Yusof, N. M. R., \& Shah, M. P. (2010). Sikap Pelajar Terhadap Pembelajaran Kemahiran Lisan Bahasa Arab Di Universiti Teknologi Mara (UiTM). GEMA OnlineTM Journal of language Studies, 10(3),15-33.

Zainuddin, Z. (2018). Students' learning performance and perceived motivation in gamified flipped-class instruction. Computers and Education, 126, 75-88. https://doi.org/10.1016/j.compedu.2018.07.003

Zainuddin, Z., \& Halili, S. H. (2016). International Review of Research in Open and Distributed Learning Flipped Classroom Research and Trends from Different Fields of Study. The International Review of Research in Open and Distributed Learning, 17(3). Retrieved from http://www.irrodl.org/index.php/irrodl/article/view/2274/3699 